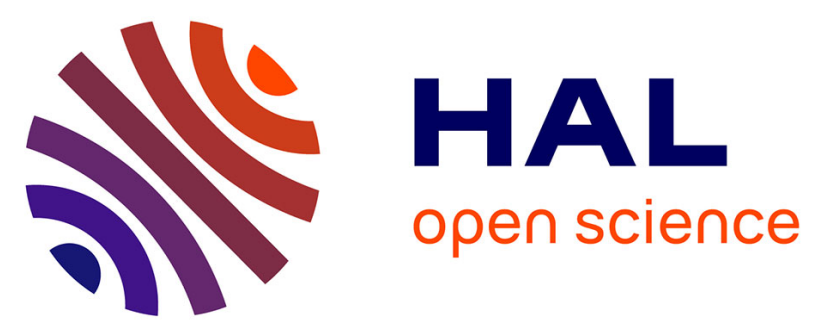

\title{
Performance of the HYDRUS-1D model for water balance components assessment of irrigated winter wheat under different water managements in semi-arid region of Morocco
}

Salah Er-Raki, Jamal Ezzahar, Olivier Merlin, Abdelhakim Amazirh, Bouchra

Ait Hssaine, Mohamed Hakim Kharrou, Saïd Khabba, Ghani Chehbouni

\section{To cite this version:}

Salah Er-Raki, Jamal Ezzahar, Olivier Merlin, Abdelhakim Amazirh, Bouchra Ait Hssaine, et al.. Performance of the HYDRUS-1D model for water balance components assessment of irrigated winter wheat under different water managements in semi-arid region of Morocco. Agricultural Water Management, 2021, 244, pp.106546. 10.1016/j.agwat.2020.106546 . hal-03068188

\author{
HAL Id: hal-03068188 \\ https://hal.science/hal-03068188
}

Submitted on 15 Dec 2020

HAL is a multi-disciplinary open access archive for the deposit and dissemination of scientific research documents, whether they are published or not. The documents may come from teaching and research institutions in France or abroad, or from public or private research centers.
L'archive ouverte pluridisciplinaire HAL, est destinée au dépôt et à la diffusion de documents scientifiques de niveau recherche, publiés ou non, émanant des établissements d'enseignement et de recherche français ou étrangers, des laboratoires publics ou privés. 
1 Performance of the HYDRUS-1D model for

2 water balance components assessment of irrigated winter wheat under

3 different water managements in semi-arid region of Morocco

4

5 S. Er-Raki(1,2)*, J. Ezzahar(2,3), O. Merlin(4), A. Amazirh(2), B. Ait Hssaine(2), M. H., 6 Kharrou ${ }^{5}$, S. Khabba(2,6), A. Chehbouni $(2,4)$

7

8 ProcEDE, Département de Physique Appliquée, Faculté des Sciences et Techniques, 9 Université Cadi Ayyad, Marrakech, Morocco

${ }^{2}$ Mohammed VI Polytechnic University (UM6P), Morocco, Center for Remote Sensing Applications (CRSA)

${ }^{3}$ MISCOM, Ecole Nationale des Sciences Appliquées, Cadi Ayyad University, Safi, Morocco

${ }^{4}$ CESBIO, Université de Toulouse, CNES/CNRS/IRD/UPS, Toulouse, France

${ }^{5}$ Mohammed VI Polytechnic University (UM6P), Morocco, International Water Research Institute (IWRI)

${ }^{6}$ LMFE, Faculty of Sciences Semlalia, Cadi Ayyad University, Marrakech, Morocco

*Corresponding author and current address:

Pr. Er-Raki Salah

ProcEDE, Département de Physique Appliquée, Faculté des Sciences et Techniques, Morocco. Tel: +212 5244334 04; Fax: +212524 433170 . 


\section{Abstract}

The main goal of this research was to evaluate the potential of the HYDRUS-1D numerical model for estimating the soil moisture $(\theta)$ at different depths, actual crop evapotranspiration (ETa) and its components (crop transpiration, Ta and soil evaporation, Ea) as well as the deep percolation (DP) of irrigated winter wheat under different water managements in the semi-arid region of Tensift-basin (central Morocco). The HYDRUS-1D simulations were performed at daily time step during the two growing seasons: 2002/2003 and 2015/2016.

The model was firstly calibrated based on one field "denoted F1" data during the 2002/2003 cropping season by using the Levenberg-Marquardt method implemented in HYDRUS-1D model for optimizing various parameters of Van Genuchten equation that provide the minimum difference between measured and simulated soil moisture at four layers of soil $(0-5,5-10,10-20,20-30,30-50 \mathrm{~cm})$. Afterwards, the model validation was done based on the data from four fields of wheat: two fields "denoted F2 and F3" during the 2002/2003 and two other fields "denoted F4 and F5" during the 2015/2016 cropping season. All fields were irrigated with flooding system except the field F5 where drip irrigation was undertaken. In-situ measurements of $\theta$ was carried out using Time Domain Reflectometry (TDR) and gravimetric method ETa was measured by the Eddy Covariance system Ta and Ea were monitored using a lysimeter in F5 field. The results showed that the HYDRUS-1D model simulates the $\theta$, ETa, Ta and Ea reasonably well.

Additionally, the evaluation of the irrigation system on DP losses was investigated by comparing the simulation results over flood (F4) and drip (F5) irrigated fields. It was found that about $56 \%$ and $20 \%$ of seasonal supplied water were lost by DP in F4 and F5 sites, respectively. Such unexpected high amount of DP taking place in F5 field is due to the improper use of the drip irrigation system..

Keywords: HYDRUS-1D; Evapotranspiration; Eddy Covariance; deep percolation; winter wheat. 


\section{1- Introduction}

In arid and semi-arid regions, water resources are currently scarce and will be one of the major challenge in the future due to the combined effect of the expected hydrological cycle alteration as a result of climate change and the sharp increase of water demand for agriculture, urban and industry (IPCC, 2009). In these regions, water scarcity is one of the main factors limiting agricultural development, and thus food security. The impact of such water scarcity is amplified by inefficient irrigation practices, especially because the irrigation system consumes more than $85 \%$ of the available water in these regions (Chehbouni et al., 2008).

In Morocco, cereals represent the main agricultural crops, accounting for about $65 \%$ of all agricultural lands, among which common wheat constitutes about $54 \%$ of the agricultural production (MADRPM, 2010). Additionally, due to the high evaporation rate $(\approx 1600 \mathrm{~mm} /$ year $)$ and erratic rainfall, the irrigation of cereals is inevitable under these conditions. Therefore, the monitoring of cereal water needs and consumption is a major challenge for developing rational irrigation strategy and for achieving higher water use efficiency. This requires an accurate estimation of the water consumed by evapotranspiration (ET) and its components (soil evaporation, Ea and plant transpiration, Ta) as well as the part lost through deep percolation DP (ErRaki et al., 2010a; Khabba et al., 2013; Nassah et al., 2018) which represent the water balance components extremely difficult to quantify. It is important to mention that the loss in terms of percolation is considered in the context of agronomy. However, it is not considered as a loss with regard to hydrology since it feeds the water table. In this regard, quantifying the two loss components (soil evaporation and deep percolation) is of paramount importance for sound irrigation management especially in water shortage situation. Reducing both loses could be one of the most important water-saving strategies in semi-arid agricultural regions.

Recently, numerous studies have been done on either measurements or estimates of ET over the annual crops such as the wheat in the Haouz plain located in the Tensift basin near to the Marrakech city (Duchemin et al., 2006; Er-Raki et al., 2007, 2010b, 2011; Ezzahar et al. 2009; Kharrou et al., 2013; Diarra et al., 2017; Ait Hssaine et al., 2018). Unfortunately, partitioning ET based on the separate measurements or 
estimates of plant transpiration and soil evaporation is technically challenging (Rafi et al., 2019). The reasons are numerous: developed technologies including lysimeters, sap flow sensors, stable isotopes (Scott et al., 2006; Wang et al., 2010; Allen et al., 2011; Kool et al., 2014) are not suitable over the wheat crop, difficulty to install sap flow sensors which can damage the monitored stems, non-continuous measurements along the growing season, costly and require a competent staff for data processing and maintenance and the difficulty for up scaling the single measurements from plant to the field scale (Kool et al., 2014).

During the last two decades, substantial efforts (e.g. Liu et al., 2002 ; Kang et al., 2003; Balwinder-Singh et al., 2011; Zhang et al., 2002; 2011; Aouade et al., 2016, Rafi et al., 2019) have made ET partitioning of wheat crop. All of these studies were generally based on the combination of micro-meteorological measurements (Bowen ratio, eddy covariance system), eco-physiological techniques (sap flow, stable isotopes) and water balance methods (lysimeters or micro-lysimeters and soil water budget). However, these techniques are not always reliable and representative at ecosystem scale due to the heterogeneous characteristics of land use and agronomical practices. Therefore, estimation of soil evaporation and plant transpiration separately with models could be a good alternative to the above measurement methods. In this context, several models have been developed to estimate evapotranspiration and its components separately. These models are generally based on water balance and/or energy balance, and ranged from complex such as the Simple Soil Plant Atmosphere SiSPAT (Braud et al., 1995) and ISBA (Noilhan and Mahfouf, 1996) to simple ones such as FAO-56 dual approach (Allen et al., 1998), HYDRUS-1D (Šimůnek et al., 2008), HYDRUS-2D/3D (Šimůnek et al., 2016). Other crop models such as AquaCrop (Raes et al., 2009), RZWQM (Ahuja et al., 2000), APSIM (McCown et al., 1996) simulate ET and its components through the combination of a water balance with a crop growth component. These models are dynamic and generally include climate module, crop module, soil module and field management module.

Regarding DP component, less attention has been paid on estimating this term although it contributes to significant loss of water if irrigation system is inadequate. DP is commonly determined as a residual in water balance equation (Sammis et al., 
1983, Willi et al., 1997; Vázquez et al., 2006; Wang et al., 2012; Hatiye et al., 2018; Nassah et al., 2018). These studies tested this method for various crops under different irrigation techniques and for different soils texture and salinity. Nevertheless, the estimation of DP with this method was not always reliable due to the uncertainties in measuring some water balance components such as ET.

Other methods such as lysimeters (Kim et al., 2011; Duncan et al., 2016), fluxmeters (Deurer et al., 2008; Gee et al, 2009) can directly measured DP. However, these methods are expensive (Upreti et al., 2015), difficult to set up and the measurements take place on a limited spatial scale (Gee et al., 2009, Rafi et al., 2018). Other indirect methods are also used such as chloride mass balance modelling (Willi et al., 1997), hydraulic method (Qinbo et al., 2011), temperature measurements in the unsaturated zone (Constantz et al., 2003) and geochemical tracers (Stonestrom et al., 2003).Since the HYDRUS-1D model has been widely used to simulate soil water movement and the water balance components (mainly infiltration, soil evaporation, transpiration and deep percolation), it is often preferred due to its simplicity when compared to heavily parameterized physically-based models. Additionally, HYDRUS-1D requires relatively few inputs parameters for calibration and the obtained results are satisfactory as reported in several investigations (e.g. Wenninger et al., 2010; Sutanto et al., 2012; Li et al., 2014; Tan et al., 2014; Han et al., 2015; Zheng et al., 2017; Xu et al., 2017; Hatiye et al., 2018). Most of these investigations have applied HYDRUS-1D model for simulating soil water movement and percolation, but there are a very few studies on the ET partitioning. For instance, one can cite the works of the Sutanto et al. (2012) and Wenninger et al. (2010) which tested the potential of HYDRUS-1D to estimate ET partitioning over grass and a teff crop based on the combination of the isotope method and the water balance equation, respectively. As reported by Kool et al., (2014), these two studies were only conducted in a laboratory set-up with no conclusive partitioning results, which indicates the need for further validation by using experimental field data. In this context, the objective of this study is to calibrate and validate the HYDRUS-1D model for estimating actual crop evapotranspiration (ETa) and its components (Ta and Ea), as well as the temporal dynamics of soil moisture at different depths $(5,10,20,30$ and 
$50 \mathrm{~cm}$ ) of irrigated winter wheat under different water managements in the semi-arid region of Tensift-basin (central of Morocco). The evaluation of the irrigation system on DP losses has been also performed.

\section{2- Materials and Methods}

\subsection{Site description}

Field experiments were conducted over wheat crops in the irrigated zone R3, approximately located $40 \mathrm{~km}$ East of Marrakech city (centre of Morocco) (Fig. 1), during both 2002/2003 and 2015/2016 growing seasons. This area has a semi-arid Mediterranean climate, characterized by low and irregular rainfall with an annual average of about $240 \mathrm{~mm}$, against an evaporative demand $\left(\mathrm{ET}_{0}\right)$ of about $1600 \mathrm{~mm}$ year-1. Most of the precipitation falls during winter and spring, from the beginning of November until the end of April (Duchemin et al., 2006, 2008; Er-Raki et al., 2007). The R3 zone has been managed since 1999 by a regional public agency (Office Regional de Mise en Valeur Agricole du Haouz (ORMVAH)) for crop irrigation.

The R3 region covers about 2800 ha and is almost flat, with deep soil of xerosol type and a fine, clay to loamy texture, developed on colluvial materials from the HighAtlas mountain range (Duchemin et al., 2006).This results in homogeneous soils and the soil hydraulic parameters have to be similar over all studied sites. The main crop grown in the region is the winter wheat (Iounousse et al., 2015). More details on the study site are provided in Duchemin et al. (2006), Er-Raki et al. (2007) and Amazirh et al. (2017).

\subsection{Field experiments}

Field experiments were carried out in five fields of winter wheat: three fields denoted "F1, F2 and F3" during the 2002/2003 cropping season and two others denoted denoted respectively as filed one, two and three in the growing seasons 2002/2003 and in the other "denoted F4 and F5" during the 2015/2016 cropping season (Fig. 1). All fields were irrigated with flooding system except the field F5 
where surface drip irrigation method was used. The irrigation amounts were about $30 \mathrm{~mm}$ for F1, F2 and F3, and about $65 \mathrm{~mm}$ for F4 in each irrigation event, while the field F5 was randomly irrigated by applying an amount varied between $15 \mathrm{~mm}$ and $45 \mathrm{~mm}$ for each water supply. Sowing dates, the lengths of wheat growth stages and the irrigation timing used in each field are provided in Table 1. The entire growing season of wheat was divided into four growth stages namely: the initial $\left(l_{i n i}\right)$, the development $\left(l_{\text {dev }}\right)$, the midseason $\left(l_{\text {mid }}\right)$ and the late season $\left(l_{\text {late }}\right)$. The lengths of growth stages were computed according to the FAO-56 method (Allen et al., 1998, Er-Raki et al,. 2011) as a fraction of canopy cover (CC).

\subsection{Data description}

The data used in this study were obtained from two experiments carried out on five irrigated wheat crops to monitor the different variables of the surface energy and water balances as well as soil and vegetation data during the 2002/2003 and 2015/2016 cropping seasons.

Meteorological data were recorded very close to the five fields by using a tower installed over a well-watered clipped grass and equipped with classical automatic sensors. Measurements included incoming solar radiation (Kipp and Zonen CM5 pyranometer, The Netherlands), air temperature and vapour pressure (HMP45C, Vaisala, Finland), wind speed (A100R anemometer, R.M. Young Company, USA) and rainfall (FSS500 tipping bucket automatic rain gauge, Campbell Inc., USA). Daily averaged values of meteorological data were calculated in order to compute the daily reference evapotranspiration $\left(\mathrm{ET}_{0}\right)(\mathrm{mm} /$ day), according to the FAO-56 Penman-Monteith equation (Allen et al., 1998; Er-Raki et al., 2010c).

On each field of wheat, an Eddy Covariance system (EC) was installed to measure the actual evapotranspiration (ETa) using high frequency measurements of the three dimensional (3D) air velocity, temperature and water vapor fluctuations. This system consists of commercially available instrumentation: a 3D sonic anemometer (CSAT3, Campbell Scientific Ltd) and an open-path infrared gas analyzer (Li7500, Licor Inc.) or fast hygrometer (KH2O, Campbell Scientific Inc., USA). Data loggers (Campbell Scientific Ltd) were used for the storage of raw $20 \mathrm{~Hz}$ 
data. The half-hourly fluxes were later calculated off-line using Eddy Covariance processing software 'ECpack', after performing all required corrections for planar fit correction, humidity and oxygen (KH20), frequency response for slow apparatus, and path length integration (Van Dijk et al., 2004). The software is available for download at http://www.met.wau.nl/. More details aboutthe description of EC measurements as well as the data processing can be found in Duchemin et al. (2006). The performance of EC measurements was assessed by checking the energy balance closure. By neglecting the term of canopy heat storage and the radiative energy used in photosynthesis (Baldocchi et al., 2000), the energy balance equation is given by:

$$
\text { Rn- } G=H+L E
$$

where $\mathrm{Rn}$ is the net radiation measured by CNR1 radiometers; $\mathrm{G}$ is the soil heat flux measured using soil heat flux plates; $\mathrm{H}$ and LE are respectively the sensible heat flux and the latent heat flux measured by eddy covariance system. By plotting the sum of the turbulent fluxes $(\mathrm{H}+\mathrm{LE})$ against the available energy $(\mathrm{Rn}-\mathrm{G})$ for five sites (data not shown here), it was found that the absolute error values of average closure was less than 20\% (Er-Raki et al., 2011; Amazirh et al., 2017, Aouade et al. 2020). This is considered as acceptable with regards to literature (Twine et al., 2000).

Soil water content was measured over the five fields (F1, F3, F4, F5) by using a Time Domain Reflectometry (TDR) (CS616, Campbell Scientific Ltd.) at different depths $(5,10,20,30,40$, and $50 \mathrm{~cm})$. TDR measurements were taken at $1 \mathrm{~Hz}$, and averages were stored at 30 min intervals on CR23X data loggers (Campbell Scientific Ltd.). Likewise, weekly measurements of soil water content in different depths were made by using the gravimetric method over F2 field. This method was also conducted over other fields in order to calibrate the TDR measurements. This method consists of using the split tube sampler to take several soil sampling at different depths $(5 \mathrm{~cm}, 10 \mathrm{~cm}, 20 \mathrm{~cm}, 30 \mathrm{~cm}$ and $50 \mathrm{~cm})$ and under different conditions (humid, moderate and dry) with a weekly frequency. Finally, the soil moisture at the root zone $(0-50 \mathrm{~cm})$ was calculated based on the weighted soil moisture in each depth.

Additionally, on weekly basis, measurements of the canopy cover (CC) and leaf area index (LAI) over each field were made using hemispherical canopy photographs 
(using a Nikon Coolpix 950 with a FC-E8 fish-eye lens converter, field of view $183^{\circ}$ ) and the metric method, respectively. For more details about those techniques and the software processing used for deriving $C$, the reader can be referred directly to Duchemin et al. (2006) and Er-Raki et al. (2007).

Besides all above measurements, two mini-lysimeters (30 cm in diamater) were installed over F5 field: one of $30 \mathrm{~cm}$ depth to measure actual soil evaporation (Ea) and another one of $90 \mathrm{~cm}$ depth to measure the actual evapotranspiration (ETa). Only the $90-\mathrm{cm}$ depth lysimeter was seeded on the same date as the entire wheat field. The 30-cm depth lysimeter was left under bare soil conditions while its immediate surroundings were kept untouched in order to reproduce the wheat field environment. To mimic the field irrigation, one single dripper per lysimeter was diverted to feed the surface soil right above the lysimeter cylinder. Both lysimeters are tension-controlled and allow for measuring the water fluxes at the surface $(30 \mathrm{~cm}$ for Ea)) and at the bottom (90 cm for ETa). Such measurements were used for validating the ETa partitioning by HYDRUS 1D model.

\subsection{Model description}

HYDRUS-1D model is a public domain Windows-based modeling environment for simulation of water, heat and solute movement (Šimůnek et al., 2008). The model numerically solves the Richards equation for variably saturated media, and the convection-dispersion equation for heat and solute transport based on Fick's law. The water flow equation includes a sink term to account for root water uptake of plants. In the present study, this model was applied to predict the soil water movement at different depths, the main components of the water balance: plant transpiration, soil evaporation and deep percolation.

The governing one-dimensional water flow equation for a partially saturated porous medium is described using the modified form of the Richards equation, under the assumptions that the air phase plays an insignificant role in the liquid flow process and that water flow due to thermal gradients can be neglected:

$$
\frac{\partial \theta}{\partial t}=\frac{\partial}{\partial x}\left[K\left(\frac{\partial h}{\partial x}+1\right)\right]-S \quad \text { (eq. 2) }
$$


where $h$ is the water pressure head $(\mathrm{cm}), \theta$ is the volumetric water content $\left(\mathrm{cm}^{3} / \mathrm{cm}^{3}\right)$, $\mathrm{t}$ is time (day), $\mathrm{x}$ is the spatial coordinate $(\mathrm{cm}), \mathrm{K}$ is the unsaturated hydraulic conductivity function (cm/day), and $S$ is the sink term in the flow equation $\left(\mathrm{cm}^{3} / \mathrm{cm}^{3} /\right.$ day) accounting for root water uptake.

The soil water retention, $\theta(h)$, and hydraulic conductivity, $K(h)$, functions according to van Genuchten (1980), are given as

$$
\begin{gathered}
\theta(h)=\left\{\begin{array}{lll}
\theta_{r}+\frac{\theta_{s}-\theta_{r}}{\left[1+|\alpha h|^{n}\right]^{m}} & h<0 \\
\theta_{s} & h>0
\end{array} \quad\right. \text { (eq. 3) } \\
K(h)=K_{s} S_{e}^{l}\left[1-\left(1-S_{e}^{\frac{1}{m}}\right)^{m}\right]^{2} \quad \text { (eq. 4) } \\
m=1-\frac{1}{n}, \quad n>1
\end{gathered}
$$

here $\theta_{\mathrm{s}}$ is the saturated water content $\left(\mathrm{cm}^{3} / \mathrm{cm}^{3}\right) ; \theta$ is the residual water content $\left(\mathrm{cm}^{3} / \mathrm{cm}^{3}\right) ; \mathrm{m}, \mathrm{a}$ and $\mathrm{n}$ are empirical shape factors in the water retention function, Ks is the saturated hydraulic conductivity $(\mathrm{cm} /$ day); $l$ is the shape factor (the pore connectivity parameter) in the hydraulic conductivity function; and Se is the relative saturation, which is expressed as:

$$
S e=\frac{\theta-\theta_{r}}{\theta_{s}-\theta_{r}} \quad \text { (eq. 5) }
$$

HYDRUS-1D model uses LAI and $\mathrm{ET}_{0}$ as the basis to calculate potential transpiration (Tp) and potential soil evaporation (Ep) at a daily time step using:

$$
\begin{aligned}
& T p=E T o\left(1-e^{-k * L A I}\right)=E T o * C C \\
& E p=E T o * e^{-k * L A I}=E T o *(1-C C)
\end{aligned}
$$

where $\mathrm{k}$ is an extinction coefficient for global solar radiation; its value was taken as 0.5 for the wheat according to Monteith and Unsworth, (1990).

Estimated Tp and Ep in conjunction with the water stress responses (Feddes et al., 1978) and the root growth distribution were then used to calculate actual plant transpiration (Ta) and actual soil evaporation (Ea). In particular, Ta is calculated by means of the following equation:

$$
T a=\int_{Z r} S(h, x) d x=\operatorname{Tp} \int_{Z r} \alpha(h) b(x) d x \quad \text { (eq. 8) }
$$

where $\mathrm{Zr}$ is the root depth, $\mathrm{S}$ is the root water uptake rate, $\alpha(\mathrm{h})$ is the water stress response function (dimensionless) and $\mathrm{b}(\mathrm{x})$ is the distribution function of water 
uptake by the root. The reader can find more details about the form of these two functions in Feddes et al. (1978) and Šimůnek et al., (2008).

Actual soil evaporation (Ea) is calculated by the following equation:

$$
E a=-K\left[\frac{\partial h(x, t)}{\partial x}+1\right] \leq E p \quad(\text { eq. 9) }
$$

\subsection{Model calibration and evaluation procedure}

The HYDRUS-1D model was calibrated on one field (F1) during 2002/2003 cropping season and then validated on four other wheat fields, denoted "F2, F3" and "F4, F5" during the 2002/2003 and 2015/2016 cropping seasons respectively, by using the same calibrated parameters. As mentioned before the soil texture in the R3 zone is uniform (clay to loamy), then the soil hydraulic parameters have to be similar over all studied sites.

The calibration was performed based on the Marquardt-Levenberg technique (Marquardt, 1963; Šimunek and Hopmans, 2002) implemented in HYDRUS-1D model for inverting the soil hydraulic parameters that provide the minimum difference between measured and simulated soil moisture at different depths $(5,10$, 20, 30 and $50 \mathrm{~cm}$ ). To this end, soil is divided into five layers and the the soilhydraulic parameters of Van Genuchten (1980) functions (see eqs. 2 and 3) were calibrated for each layer (Table 2). The obtained value of soil residual water content $(\theta \mathrm{r})$ was $0.0945 \mathrm{~cm}^{3} / \mathrm{cm}^{3}$ and it is similar for all layers, while the soil saturation water content differs from the shallow layer to deeply one depending on soil texture. Other parameters for soil water retention curve (Van Genuchten, 1980) such as Ks, a, n and 1 were also calibrated in each layer (Table 2). The calibrated values of Ks and $\theta$ s are in concordance with the values found by Toumi et al., (2016) who calibrated the AquaCrop model for winter wheat over the same study area. For the other parameters of Van Genuchten equation ( $a, n$ and 1$)$, the calibrated values are in agreement with other finding (e.g. Ghanbarian-Alavijeh et al., 2010; Li et al., 2014; Jyotiprava Dash et al., 2015; Wallor et al., 2018; Latorre and Moret-Fernández, 2019) who again calibrated the HYDRUS-1D model for different soil textures. Some of these studies (Li et al., 2014; Wallor et al., 2018) determined the soil hydraulic parameters by using the RETC software package through fitting the retention data $\theta(h)$. 
Finally, the performance of the HYDRUS-1D model was evaluated using statistical parameters: the correlation coefficient $\left(\mathrm{R}^{2}\right)$ and the Root Mean Square Error (RMSE), which measure the correlation and the discrepancy of simulated values around observed ones, respectively for both the calibration/validation stages. The correlation coefficient $\left(\mathrm{R}^{2}\right)$ and the Root Mean Square Error (RMSE) are given by:

$$
\begin{gathered}
R M S E=\sqrt{\frac{1}{N} * \sum_{i=1}^{N}\left(y_{i s i m}-y_{i o b s}\right)^{2}} \\
R^{2}=\left[\frac{\sum_{i=1}^{N}\left(y_{i s i m}-\overline{y_{l s l m}}\right)\left(y_{i o b s}-\overline{y_{\text {lobs }}}\right)}{\sum_{i=1}^{N}\left(y_{i s i m}-\overline{y_{l s l m}}\right) \sum_{i=1}^{N}\left(y_{i o b s}-\overline{y_{\text {lobs }}}\right)}\right]^{2}
\end{gathered}
$$

where $\bar{y}_{\text {sim }}$ and $\bar{y}_{o b s}$ are the averages of model and observations, respectively, $N$ is the number of available observations, and $y_{i s i m}$ and $y_{i o b s}$ are the daily values of modeled and observed variables, respectively.

\section{3- Results and discussions}

In this section, the results of the calibration and the validation processes of HYDRUS-1D model by exploiting the data collected during two cropping seasons (2002/2003 and 2015/2016) are presented. Since the different components for ETa partitioning were measured on one field (F5) during 2015/2016 by using the weighing mini-lysimeters, an attempt was made to validate the ETa partitioning through the comparison between measured and simulated actual plant transpiration (Ta) and soil evaporation (Ea). As HYDRUS-1D model is able to simulate deep percolation water (DP), the evaluation of the irrigation method (drip and flood) in terms of DP losses will be also discussed at the end of this section.

\section{3-1 Model Calibration}

As mentioned above, the calibration of the different parameters of the hydraulic functions of van Genuchten (1980) used in HYDRUS-1D model was based on the comparison between measured and simulated soil moisture at different depths $(5,10$, 20, 30 and $50 \mathrm{~cm}$ ). Fig. 2 shows this comparison which showed a good agreement between simulated and measured volumetric soil water content $(\theta)$ for all depths. According to this figure, the dynamics of $\theta$ was adequately simulated and followed 
the trend of the measured values with some under-estimation of $\theta$ during the peak values for upper layer $(5 \mathrm{~cm})$. Seemingly, the soil water content in the upper soil layers produced more changes than in the deeper soil layers when the soil was not fully covered. The same behavior of surface soils was revealed by Han et al., (2015) when applying HYDRUS-1D model over a cotton crop in northwest of the Tarim Basin in the Xinjiang province of northwestern China. However, once the canopy cover reaches its maximum, the simulated and measured soil water content becomes very close even during the irrigation and rainfall events.

Likewise, it can be clearly seen that the simulations as well as the measurements respond well to water supply (irrigation and rainfall). For the integrated evaluation of soil moisture simulations, the measured root-weighted soil moisture with the simulated one we compared (fig 2-f). It is clear that the model correctly simulates the integrated $\theta$ at the root zone. The corresponding values of $\mathrm{R}^{2}$ and RMSE are 0.87 and $0.02 \mathrm{~cm}^{3} / \mathrm{cm}^{3}$ and, respectively.

The model performance was also evaluated during the calibration stage by comparing the measured and simulated actual evapotranspiration (ETa) values. The correspondence between measured and simulated ETa is shown as daily time course and in the scatter plot displayed in Fig. 3. A good agreement $\left(R^{2}=0.83\right.$ and RMSE $=0.90 \mathrm{~mm} /$ day) between simulated and measured ETa was found. The model produced slightly lower values of ETa than those observed. This underestimation of ETa in field F1 is expected and is attributed to the presence of the wild oat which was randomly developed in this field (Duchemin et al., 2006) during 2002/2003 season. Generally speaking, this wild oat that invaded this field increases the Leaf Area Index (LAI) and consequently the measured $\mathrm{ET}_{\mathrm{a}}$ by eddy covariance system. The model was driven by an average value of LAI calculated by averaging all measurements taken along several transects using the allometric method, which means that the simulated ETa is more or less representative for the whole wheat only. In contrary, the measured ETa is limited to the footprint of the eddy covariance system. Therefore, any extra wild oat within this footprint can increase LAI (wild and wheat) and thus measured ETa. The same behavior has been remarked by Toumi et 
al., (2016) when using the same data for calibrating AquaCrop model that uses CC instead of LAI for crop development monitoring over the same field.

Additionally, by comparing the statistical results obtained by Toumi et al. (2016) $\left(\mathrm{R}^{2}=0.69\right.$ and $\mathrm{RMSE}=1.07 \mathrm{~mm} /$ day $)$, it is clearly seen that albeit of its hydrological aspect, HYDRUS-1D simulates better ETa than agronomical model AquaCrop. Over the same field, Aoaude et al. (2020) have calibrated new multiple energy balance (MEB) version of ISBA (Interaction Soil Biosphere Atmosphere) developed recently by Boone et al. (2017) and their results of $R^{2}$ and RMSE values were about 0.73 and $2.6 \mathrm{~mm} /$ day which are slightly less performing than those obtained by HYDRUS-1D. Consequently, one can confirm the potential of HYDRUS-1D model for estimating ETa compared to ISBA-MEB model which is very complex and requires many input parameters to run it.

\section{3-2 Validation of HYDRUS-1D model}

After the calibration of the HYDRUS-1D model, model validation was performed using the dataset collected over four other wheat fields: two fields named F2 and F3 during the 2002/2003 and two other ones named F4 and F5 during 2015/2016 cropping season.

In order to limit the number of figures, only results for the weighted soil moisture at the root zone layer $(0-50 \mathrm{~cm})$ are presented in Fig. 4 for four validation fields (F2, F3, F4 and F5). It should be noted that the weighted soil moisture over F2 field was calculated based on the measurements of the gravimetric method. As the calibration stage, HYDRUS-1D model was also able to simulate accurately the soil water content $(\theta)$ for all fields at different depths (data not shown here). Indeed, the simulated values of the weighted volumetric soil water content are in agreement with observed values for all fields, and their dynamics consistently reflected the rainfall and irrigation events (Fig. 4). However, some discrepancies between measured and simulated $\theta$ were observed, particularly for high values where the model cannot effectively capture the observed data during some periods for some fields (14 to 22 April for F2 and around DOY 74 for F3). The same observation was revealed by Silva Ursulino et al., (2018) and Grecco et al., (2019) when applying HYDRUS-1D and 
HYDRUS-2D models, respectively, for predicting soil water content dynamics in two experiments in Brazil. A possible explanation for this underestimation of $\theta$ by the model may be due to the overestimation of evapotranspiration rates, which can reduce the soil moisture rates as reported by Silva Ursulino et al., (2018). Additional explanation of the difference between measured and simulated $\theta$ values is related to the assumption of a constant value for the root depth in HYDRUS-1D/2D, which considered an important limitation of the model (Grecco et al., 2019).

One can also note that the soil water content for drip field (F5), decreased rapidly within a few days after irrigation (e.g. March 23 to April 07), whereas it decreased slightly for flood irrigation (F4) during the same period. This can be explained by the rapid soil drying linked to the limited wetted fraction of soil, compared to the flood system where the soil is completely wetted which promotes the horizontal diffusion of water. Another factor that may partly explain this difference is the root water uptake (S) patterns under two irrigation systems. In the same context, Xue et al., (2003) and Eugenio and Dani (1999) investigated the effect of available soil water and irrigation type on root distribution and water uptake patterns over wheat and corn crops, respectively. They found a significant correlation between the root water uptake and the irrigation system (flood and drip) as well as the available soil water. It can be seen also that the simulated and the measured soil water content remained almost above field capacity (about $0.32 \mathrm{~cm}^{3} / \mathrm{cm}^{3}$ ) for most of time especially for field F5 due to the high amounts of delivered irrigation. Consequently, the excess water can percolate to deep soil layers (see § 3.4).

Based on the values of RMSE $\left(0.06,0.04,0.02\right.$ and $0.01 \mathrm{~cm}^{3} / \mathrm{cm}^{3}$ for F2, F3, F4 and F5, which represents a relative error of $22,16,6.66$ and $3.44 \%$, respectively), it can be concluded that the model performed well in simulating volumetric soil water content.

Concerning the validation of HYDRUS-1D simulations of ETa, Fig. 5 shows the comparison between the daily simulated and measured ETa for two validation fields (F2 and F3) during 2002/2003 and two other validation fields (F4 and F5) during 2015/2016 cropping seasons. The scatter plot reveals a good agreement between simulated and measured ETa. The RMSE $\left(R^{2}\right)$ values were 
$0.44(0.83), 0.40(0.87), 0.68(0.69)$ and $0.55(0.76) \mathrm{mm} /$ day for F2, F3, F4 and F5, respectively. The slope of the linear regression is about $0.96,0.84$ and 1.05 for F2 and F3, F4 and F5 fields, meaning that the model underestimates ETa by about $4 \%$ and 16\% for F2 and F3, F4 and overestimates ETa by about 5\% for F5. According to those statistical results, it can be concluded that although its relative simplicity, the HYDRUS-1D model can estimate very well ETa through the sum of the transpiration calculated with the root water uptake function (eq. 8) and soil evaporation (eq. 9), as shown by many authors (e.g. Li et al., 2014; Phogat et al., 2010). The question addressed after is how efficiently this model simulates the two components of evapotranspiration individually: plant transpiration (Ta) and soil evaporation (Ea).

\subsection{Performance of the HYDRUS-1D model for partitioning of soil evaporation and plant transpiration}

As HYDRUS-1D model computes separately actual transpiration (Ta) and soil evaporation (Ea), it is of interest to investigate how well these individual components are simulated. To achieve this objective, we used the measurements of two minilysimeters in F5 field: one installed beneath the crop in order to measure ETa and another one under the bare soil to get the measurements of Ea. Plant transpiration (Ta) was derived as the difference between ETa and Ea. Fig. 6 presents the comparison between the measured and simulated ETa, Ta and Ea. Daily patterns of the simulated and measured values of each term are similar. The magnitude of daily Ta (Ea) was the lowest (highest) at the beginning of the season and it increased (decreased) continuously up to full development following the LAI increase. Instantaneous clear rise in Ea values respond well to water supply events (Fig. 6-b). The results showed that HYDRUS-1D model gives an acceptable estimate of plant transpiration and soil evaporation separately. In addition to the good performance of the model in terms soil moisture dynamics, the result indicates that the water uptake described in Eq. (8) is robust enough to capture the transpiration component. The associated RMSE between measured and simulated values of ETa, Ea and Ta were 
0.54, 0.73 and $0.65 \mathrm{~mm}$ / day, respectively. The performance of HYDRUS-1D model in simulating ETa was similar when compared to different systems measurements (eddy covariance and lysimeter) which confirms an accurate calibration and validation of the model. For soil evaporation (Fig. 6-b), the difference between the measurements and the simulations is attributed to the fact that the lysimetre was over-irrigated because the dripper is intended to irrigate a surface of $0.4 \mathrm{~m}^{2}$ bigger than the area of lysimetre. This results that the lysimetre receives a larger quantity of irrigation water.

\section{3-4 Deep percolation losses}

Deep percolation (DP) is an important component of water balance, but it is rarely quantified for different types of irrigation. For that, we propose to evaluate the DP losses over two irrigated wheat plots: flood (F4) and drip (F5), by using both HYDRUS-1D and direct measurements with mini-lysimeter. Firstly, we analyze the effect of the irrigation type on DP by using HYDRUS-1D simulations (Fig. 7-a). Then, the validation of the DP estimation has been performed over drip plot (F5) where the measurements are available at two depths $(30$ and $90 \mathrm{~cm})($ Fig. 7-b).

According to Fig. 7-a, the simulations of DP for both fields (F4 and F5) respond well to water supply (irrigation and rainfall). After irrigation or rainfall, as expected, DP increased in two fields, but with different increasing magnitudes. In general, DP is higher for flood irrigation (F4) compared with drip irrigation (F5). This is expected because with flooding technique, the soil was completely wetted with higher amount of irrigation. Then, more amount irrigations in each water supply resulted in more water loss by DP. The cumulated simulated DP values of the entire experimental period are 93 and $347 \mathrm{~mm}$ for drip (F5) and flood (F4) irrigation, respectively. This amount represents about 20 and $56 \%$ of water supply (irrigation and rainfall). This difference could be attributed to the fact that the amount of flood irrigation for each supply was higher (about $64 \mathrm{~mm}$ ) which promotes the DP. Another factor that may partly explains this difference is that the irrigation in plot F4 coincides with some rainfall events (February 19th, March 22th) and that might have increased the DP. The lowest magnitude of DP observed after the end of March could be explained by 
512 the high crop evapotranspiration (linked to the crop maturity and root growth) 513 which was closely associated with the root water uptake (Tafteh and Sepaskhah, 514 2012). Similar results were obtained by Jyotiprava Dash et al., (2015) and Xu et al., (2017) when they applied HYDRUS-1D model for DP evaluation under different irrigation practices for rice crop, and they found an important amount (about 55\%) of the applied water percolate below the root zone.

As mentioned above, DP simulations were compared to the measurements over drip plot (F5) where the measurements are available at two depths (30 and $90 \mathrm{~cm})$ (Fig. 7-b). Missing data in some days is associated to power supply failures. According to Fig. 7-b, the DP at $90 \mathrm{~cm}$ depth is almost zero which might be related to the soil texture (more clay) that avoid the irrigated water to reach this depth. For other depths, both simulated and measured increased (with different magnitude) after water supply have decreased quickly and equal to zero in dry conditions (absence of irrigation and rainfall). As the measurements of DP with lysimeter are not complete and sometimes uncertain due to lack of spatial representativeness of the lysimeter irrigation, it is difficult to discuss more deeply about the comparison between the measurements and the simulations. Then, further effort would be necessary for more accurate measurements of DP in order to correctly validate the HYDRUS-1D simulations.

\section{4- Conclusions}

Good agreement was achieved to estimate $\theta$ and ETa between the HYDRUS-1D simulations and field measurements for winter wheat under different water managements, indicated by low average values of RMSE, which are $0.03 \mathrm{~cm}^{3} / \mathrm{cm}^{3}$ for $\theta$ and $0.58 \mathrm{~mm} /$ day for ETa. Validation of ETa partitioning by the model based on lysimeters measurements showed that the model gives acceptable estimates of Ea and Ta, with associated RMSE equal to 0.73 and $0.65 \mathrm{~mm}$ /day, respectively.

Deep percolation (DP) losses was also evaluated under drip and flood irrigations.. As expected, the simulation results showed that a seasonal amount of DP losses for flood irrigation (about $347 \mathrm{~mm}$ ) was greater than for drip irrigation (93 mm), which 
543 represent about $56 \%$ and $20 \%$ of water supply (irrigation and rainfall). DP simulations were also compared to the measurements taking place in drip field at two depths (30 and $90 \mathrm{~cm}$ ). The results showed that the measured DP at $90 \mathrm{~cm}$ depth is almost close to zero indicating that the irrigation water does not infiltrates deeply which may be related to the heavy soil texture (clay). While for the other depth, both measured and simulated DP were noteworthy during the wetting events.

Finally, this study can be considered as the basis for future assessment of irrigation efficiency under drip and flood systems, and for irrigation scheduling in order to avoid the DP and Ea losses. However, further effort will be necessary for accurate measurements of DP by mini-lysimeter in order to correctly validate the HYDRUS-1D simulations.

\section{5- Acknowledgements}

This research was conducted within the International Joint Laboratory TREMA (http://lmi-trema.ma), and funded by the European Commission Horizon 2020 Programme for Research and Innovation (H2020) in the context of the Marie Sklodowska-Curie Research and Innovation Staff Exchange (RISE) action (REC project, grant agreement no: 645642), followed by ACCWA project, grant agreement no. 823965). Other findings were provided by the CNRST-SAGESSE and PRIMAIDEWA projects. We also would like to appreciate the valuable and constructive comments by the editors and the anonymous reviewers, which helped us to improve the manuscript.

\section{6- References}

Ahuja, L.R., Rojas, K.W., Hanson, J.D., Shaffer, M.J., Ma, L. 2000. Root Zone Water Quality Model: Modeling Management Effects on Water Quality and Crop Production, Water Resources Publications, LLC, Highlands Ranch, CO (2000).

Allen, R.G, L.S Pereira, D Raes, M Smith. 1998. Crop Evapotranspiration. Guidelines for Computing Crop Water Requirements, Irrigation and Drain, 56 (3): 42-48.

Allen, R. G. Pereira, L.S., Howell,T. A., Jensen, M. E.. 2011. Evapotranspiration information reporting: I. Factors governing measurement accuracy. Agr. Water Manage, 98, 899-920. 
Amazirh, A., Er-Raki, S., Chehbouni, A., Rivalland, V., Diarra, A., Khabba, S., Ezzahar, J., Merlin, O. 2017. Modified Penman-Monteith equation for monitoring evapotranspiration of wheat crop: Relationship between the surface resistance and remotely sensed stress index. Biosystems Engineering.164, 68-84.

Aouade, G., Ezzahar, J., Amenzou, N., Er-Raki, S., Benkaddour, A., Khabba, S., Jarlan, L. 2016. Combining stable isotopes and micrometeorological measurements for partitioning evapotranspiration of winter wheat into soil evaporation and plant transpiration in a semi-arid region. Agricultural Water Management. 177(1), 181-192.

Aouade, G., Jarlan, L., Ezzahar, J., Er-Raki, S., Napoly, A., Benkaddour, A., Khabba, S., Boulet, G., Garrigues, B., Chehbouni, A., Boone, A. Evapotranspiration partition using the multiple energy balance version of the ISBA-A-gs land surface model over two irrigated crops in a semi-arid Mediterranean region (Marrakech, Morocco). Hydrol. Earth Syst. Sci. Discuss., https:// doi.org/10.5194/hess, 2020.

Baldocchi DD, Law BE, Anthoni PM. 2000. On measuring and modeling energy fluxes above the floor of a homogeneous and heterogeneous conifer forest. Agricultural and Forest Meteorology 102: 187-206.

Balwinder-Singh, Eberbach, P.L., Humphreys, E., Kukal, S.S., 2011. The eff ect of rice straw mulch on evapotranspiration, transpiration and soil evaporation of irrigated wheat in Punjab. India. Agric. Water Manage. 98 (12), 1847-1855.

Boone, A., Samuelsson, P., Gollvik, S., Napoly, A., Jarlan, L., Brun, E., \& Decharme, B.: The interactions between soil-biosphere-atmosphere land surface model with a multi-energy balance (ISBA-MEB) option in SURFEXv8-Part 1: Model description. Geosci. Model Dev., 10(2), 843-872, 2017.

Braud, I., Dantas-Antonino, A.C., Vauclin, M., Thony, J.L., Ruelle, P. 1995. A simple soil-plant-atmosphere transfer model (SiSPAT) development and field verification. J. Hydrol. 166, 213-250.

Chehbouni, A., Escadafal, R., Boulet, G., Duchemin, B., Simonneaux, V., Dedieu, G.,Mougenot, B., Khabba, S., Kharrou, H., Merlin, O., Chaponnière, A., Ezzahar, J., Er-Raki, S., Hoedjes, J., Hadria, R., Abourida, H., Cheggour, A., Raibi, F., 
Hanich, L., Guemouria, N., Chehbouni, Ah., Lahrouni A., Olioso, A., Jacob, F., Sobrino, J., 2008. The Use of Remotely Sensed data for Integrated Hydrological Modeling in Arid and Semi-Arid Regions: the SUDMED Program. International Journal of Remote sensing, 29: 5161 - 5181.

Constantz, J., Tyler, W., \& Kwicklis E. (2003). Temperature-profile methods for estimating percolation rates in arid environments.Vadose Zone Journal, 2, 12-24.

Deurer, M., Clothier, B. E., Green, S. R., \& Gee G., (2008). Infiltration rate, hydraulic conductivity and preferential flow. In: S. D. Logsdon, D. Clay, D. Moore, \& T. Tsegaye (Eds.), Soil Science: Step-by-step Field Analyses (pp. 221-233). USA: Soil Science Society of America.

Diarra, A.; Jarlan, L.; Er-Raki, S.; Le Page, M.; Aouade, G.; Tavernier, A.; Boulet, G.; Ezzahar, J.; Merlin, O.; Khabba, S. Performance of the two-source energy budget (TSEB) model for the monitoring of evapotranspiration over irrigated annual crops in North Africa. Agric. Water Manag. 2017, 193, 71-88.

Duchemin, B., Hadria, R., Er-Raki, S., Boulet, G., Maisongrande, P., Chehbouni, A., Escadafal, R., Ezzahar, J., Hoedjes, J., Karrou, H., Khabba, S., Mougenot, B., Olioso, A., Rodriguez, J.-C., Simonneaux, V., 2006. Monitoring wheat phenology and irrigation in Central Morocco: on the use of relationship between evapotranspiration, crops coefficients, leaf area index and remotely-sensed vegetation indices. Agric. Water Manage. 79, 1-27.

Duchemin, B., Hagolle O., Mougenot B., Simonneaux V., Benhadj I., Hadria R., Ezzahar J., Hoedjes J., Khabba S.,. Kharrou M.H, Boulet G., Dedieu G., Er-Raki S., Escadafal R., Olioso A., Chehbouni A.G. 2008. Agrometerological study of semi-arid areas: an experiment for analysing the potential of FORMOSAT-2 time series of images in the Tensift-Marrakech plain. International Journal of Remote Sensing, 29: 5291-5299.

Duncan, M. J., Srinivasan, M. S., \& Mc Millan H. (2016). Field measurement of groundwater recharge under irrigation in Canterbury, New Zealand, using drainage lysimeters. Agricultural Water Management, 166, 17-32. 
Eugenio F. Coelho and Dani Or. 1999. Root distribution and water uptake patterns of corn under surface and subsurface drip irrigation. Plant and Soil 206: 123-136, 1999.

Er-Raki, S., Chehbouni, A., Guemouria, N., Duchemin, B., Ezzahar, J., Hadria, R., 2007.Combining FAO-56 model and ground-based remote sensing to estimate water consumptions of wheat crops in a semi-arid region. Agric. Water Manage. $14,41-54$.

Er-Raki, S., Chehbouni, A., Boulet, G., Williams, D.G. 2010a.Using the dual approach of FAO-56 for partitioning ET into soil and plant components for olive orchards in a semi-arid region.Agricultural Water Management. 97: 1769-1778.

Er-Raki, S.; Chehbouni, A.; Duchemin, B. 2010b. Combining satellite remote sensing data with the FAO-56 dual approach for water use mapping in irrigated wheat fields of a semi-arid region. Remote Sens. 2010, 375-387.

Er-Raki, S., Chehbouni, A., Khabba, S., Simonneaux, V., Jarlan, L., Ouldbba, A., Rodriguez, J.C., Allen, R. 2010c. Assessment of reference evapotranspiration methods in semi-arid regions: Can weather forecast data be used as alternate of ground meteorological parameters? Journal of Arid Environments, 74: 15871596.

Er-Raki, S., Chehbouni, A., Ezzahar, J., Khabba, S., Lakhal, E.K. Duchemin, B., 2011. Derived crop coefficient for winter wheat using different reference evpotranspiration estimates methods. Journal of Agricultural Science and Technology, 13: 209-221.

Ezzahar, J., Chehbouni, A., Er-Raki, S., and Hanich,L.: Combining a Large Aperture Scintillometer and estimates of available energy to derive evapotranspiration over several agricultural fields in semi-arid regions. Plant Biosystems. 143, 209221, 2009.

Feddes, R.A., Kowalik, P.J., Zaradny, H., 1978. Simulation of Field Water use and Crop Yield. Center for Agricultural Publishing and Documentation (PUDOC), Wageningen, The Netherlands, p. 189.

Gee, G. W., Newman, B. D., Green, S. R., Meissner, R., Rupp, H., Zhang, Z. F., Keller, J. M., Waugh, W. J., van der Velde, M., \& Salazar J. (2009). Passive wick 
fluxmeters: Design considerations and field applications. Water Resources Research, 45, 1-18.

Ghanbarian-Alavijeh, B., Liaghat, A., Guan-Hua, H., Th. Van Genuchten, M. 2010. Estimation of the van Genuchten Soil Water Retention Properties from Soil Textural Data. Pedosphere, 20(4): 456-465.

Greccoa, K. L., de Mirandaa, J.H., Silveiraa, L.K., van Genuchten, M.Th. 2019. HYDRUS-2D simulations of water and potassium movement in drip irrigated tropical soil container cultivated with sugarcane. Agricultural Water Management 221 (2019) 334-347.

Han, M., C. Zhao, J. Šimůnek, and G. Feng. 2015. Evaluating the impact of groundwater on cotton growth and root zone water balance using Hydrus-1D coupled with a crop growth model, Agricultural Water Management, 160, 641385 75, doi:10.1016/j.agwat.2015.06.028.

Hatiye, S.D., Hari Prasad, K. S., Ojha, C.S.P. 2018. Deep Percolation under Irrigated Water-Intensive Crops. Journal of Irrigation and Drainage Engineering 144(8); DOI: 10.1061/(ASCE)IR.1943-4774.0001326.

Hssaine, B.A., Merlin, O., Rafi, Z., Ezzahar, J., Jarlan, L., Khabba, S., Er-Raki, S. Calibrating an evapotranspiration model using radiometric surface temperature, vegetation cover fraction an, near-surface soil moisture data. Agric. For. Meteorol. 2018, 256-257, 104-115.

Iounousse, J., Er-Raki, S., Elmotassadeq, A., Chehouani, H. 2015. Using an unsupervised approach of Probabilistic Neural Network (PNN) for land use classification from multitemporal Satellite images. Applied Soft Computing 30: 1-13.

IPCC: Intergovernmental Panel on Climate Change (IPCC), http://www.ipcc.ch/, 2009.

Jyotiprava Dash, Ch., Sarangi, A., Singh, D. K., Singh, A. K., Adhikary, Partha Pratim. 2015. Prediction of root zone water and nitrogen balance in an irrigated rice field using a simulation model. Paddy and water environment 2015, 13, 281290. 
695

696

697

698

699

700

701

702

703

704

705

706

707

708

709

710

711

712

713

714

715

716

717

718

719

720

721

722

723

724

Kang, S., Gu, B., Du, T., Zhang, J., 2003. Crop coefficient and ratio of transpiration to evapotranspiration of winter wheat and maize in a semi-humid region. Agric. Water Manage. 59 (3), 239-254.

Kim, Y., Jabro, J. D., \& Evans R. G. (2011). Wireless lysimeters for real-time online soil water monitoring. Irrigation Science, 29 (5), 423-430.

Khabba, S., Jarlan L., Er-Raki S., Le Page M, Ezzahar J., Boulet, G., Simonneaux, V., Kharrou, M.H., Hanich, L. Chehbouni, G. 2013. The SudMed program and the Joint International Laboratory TREMA: A decade of water transfer study in the Soil-Plant- Atmosphere system over irrigated crops in semi-arid area. Procedia Environmental Sciences. 19: 524-533.

Kharrou, M.H., Le Page, M., Chehbouni, A., Simonneaux, V., Er-Raki, S., Jarlan, L., Ouzine, L., Khabba, S., Chehbouni, G. 2013. Assessment of Equity and Adequacy of Water Delivery in Irrigation Systems Using Remote Sensing-Based Indicators in Semi-Arid Region, Morocco. Water Resources Management. 27(13): 46974714.

Kool, D., Agam, N., Lazarovitch, N., Heitman, J.L., Sauer, T.J., Ben-Gal, A., 2014. A review of approaches for evapotranspiration partitioning. Agric. For. Meteorol. 184, 56-70.

Latorre, B., Moret-Fernández, D. 2019. Simultaneous estimation of the soil hydraulic conductivity and the vanGenuchten water retention parameters from an upward infiltration experiment. Journal of Hydrology, 572, 461-469.

Li, Y., Šimůnek, J., Jing, L.F., Zhang, Z.T., Ni, L.X., 2014. Evaluation of water movement and water losses in a direct-seeded-rice field experiment using Hydrus-1D. Agric. Water Manag. 142, 38-46

Liu, C., Zhang, X., Zhang, Y., 2002. Determination of daily evaporation and evapotranspiration of winter wheat and maize by large-scale weighing lysimeter and microlysimeter. Agric. For. Meteorol. 111 (2), 109-120.

MADRPM, 2010. L'agriculture Marocaine en chiffres. Ministère Marocain de l'Agriculture, du Développement Rural et des Pêches Maritimes, plan Maroc vert, Rapport interne, pp. 15. 
Marquardt, D. W. 1963. An algorithm for least-squares estimation of nonlinear parameters. SIAM J. Appl. Math. 11(2): 431-441.

McCown, R.; Hammer, G.; Hargreaves, J.; Holzworth, D.; and Freebairn, D. 1996. APSIM: A novel software system for model development, model testing and simulation in agricultural systems research. Agric. Syst. 1996, (50), pp. 255-271.

Monteith, J.L. and M.Unsworth, (1990). Principles of Environmental Physics, 2nd Edition Edward, Arnold, London.

Noilhan, J., Mahfouf, J.F. 1996. The ISBA land surface parameterisation scheme. Global and Planetary Change, 13:145-159.

Nassah, H., Er-Raki, S., Khabba, S., Fakir, Y., Raibi, F., Merlin, O., Mougenot, B. 2018. Evaluation and analysis of deep percolation losses of drip irrigated citrus crops under non-saline and saline conditions in a semi-arid area. Biosystems Engineering.165, 10-24.

Phogat, V., Skewes, M.A., Cox, J.W., Sanderson, G., Alam, J., Šimůnek, J. 2014. Seasonal simulation of water, salinity and nitrate dynamics under drip irrigated mandarin (Citrus reticulata) and assessing management options for drainage and nitrate leaching. J. Hydrol., 513 (2014), pp. 504-516.

Qinbo, C., Chen, Xi., Xunhong, C., Zhicai, Z., \& Minhua L. (2011). Water infiltration underneath single-ring permeameters and hydraulic conductivity determination. Journal of Hydrology, 398 (1-2), 135-143.

Raes, D., Steduto, P., Hsiao, T.C., Fereres, E., 2009a. AquaCrop-the FAO crop model to simulate yield response to water. II. Main algorithms and software description. Agron. J. 101, 438-447.

Rafi, Z.; Merlin, O.; Le Dantec, V.; Khabba, S.; Mordelet, P.; Er-Raki, S.; Amazirh, A.; Olivera-Guerra, L.; Ait Hssaine, B.; Simonneaux, V.; et al. Partitioning evapotranspiration of a drip-irrigated wheat crop: Inter-comparing eddy covariance-, sap flow-, lysimeter- and FAO-based methods. Agric. For. Meteorol. 2019, 265, 310-326.

Sammis, T. W., Evans, D. D., \& Warrick A. W. (1983). Comparison of methods to estimate deep percolation rates. Water Resources Bulletin, 18 (3), 465-470. 
Scott, R.L., Huxman, T.E., Cable, W.L., Emmerich, W.E., 2006. Partitioning of evapoTranspiration and its relation to carbon dioxide exchange in a Chihuahuan Desert shrubland. Hydrol. Process. 20, 3227-3243.

Silva Ursulino, B.; Maria Gico Lima Montenegro, S.; Paiva Coutinho, A.; Hugo Rabelo Coelho, V.; Cezar dos Santos Araújo, D.; Cláudia Villar Gusmão, A.; Martins dos Santos Neto, S.; Lassabatere, L.; Angulo-Jaramillo, R. 2019. Modelling Soil Water Dynamics from Soil Hydraulic Parameters Estimated by an Alternative Method in a Tropical Experimental Basin. Water 2019, 11, 1007.

Šimůnek, J., van Genuchten, M.Th., Šejna, M. 2016. Recent developments and applications of the HYDRUS computer software packages Vadose Zone J., 15 (7), p. 25, 10.2136/vzj2016.04.0033.

Šimůnek, J., M.Th . van Genuchten, and M. Šejna. 2008. Th e HYDRUS-1D software package for simulating the one-dimensional movement of water, heat, and multiple solutes in variably-saturated media. Version 4.0. HYDRUS Software Ser. 3. Dep. of Environmental Sciences, Univ. of California, Riverside.

Šimůnek, J., and J. W. Hopmans. 2002. Chapter 1.7: Parameter optimization and nonlinear fitting. In Methods of Soil Analysis: Part 1. Physical Methods, 139-157. J. H. Dane and G. C. Topp, eds. 3rd ed. Madison, Wisc.: SSSA.

Stonestrom, D. A., Prudic, D. E., Laczniak, R. J., Akstin, K. C., Boyd, R. A., \& Henkelman K.K. (2003). Estimates of deep percolation beneath irrigated fields, native vegetation, and the Amargosa River channel, Amargosa Desert, Nye County, Nevada: U.S. Geological Survey Open-File Report 03-104, 83 p.

Sutanto, S.J., Wenninger, J., Coenders-Gerrits, A.M.J., Uhlenbrook, S., 2012. Partitioning of evaporation into transpiration, soil evaporation and interception: a comparison between isotope measurements and a HYDRUS-1D model. Hydrol. Earth Syst. Sci. 16, 2605-2616.

Tafteh, A, Sepaskhah, A.R. 2012. Application of HYDRUS-1D model for simulating water and nitrate leaching from continuous and alternate furrow irrigated rapeseed and maize fields. Agricultural Water Management 113, 19-29. 
Tan, X., Shao, D., Liu, H., 2014. Simulating soil water regime in lowland paddy fields under different water managements using HYDRUS-1D. Agric. Water Manag. 132, 69-78.

Toumi, J., Er-Raki, S., Ezzahar, J., Khabba, S., Jarlan, L., Chehbouni, A. Performance assessment of AquaCrop model for estimating evapotranspiration, soil water content and grain yield of winter wheat in Tensift Al Haouz (Morocco): Application to irrigation management. Agricultural Water Management. 163(1):219-235.

Twine TE, Kustas WP, Norman JM, Cook DR, Houser PR, Meyers TP, Prueger JH, Starks PJ, Wesly ML. 2000. Correcting Eddy-Covariance Flux Underestimates over a Grassland. Agricultural and Forest Meteorology 103: 279-300.

Upreti, H., Ojha, C. S. P., \& Hari P. K. S. (2015). Estimation of Deep Percolation in Sandy-Loam Soil using Water balance Approach. Irrigation Drainage Systems Engineering. S1:002. doi:10.4172/2168-9768.S1-002.

Van Dijk, A., Moene, A.F. and De Bruin, H.A.R., 2004. The principles of surface flux physics: theory, practice and description of the ECPACK library. Internal Report 2004/1, Meteorology and Air Quality Group, Wageningen University, Wageningen, The Netherlands, 99 pp.Van Genuchten, M. Th., A closed-form equation for predicting the hydraulic conductivity of unsaturated soils, Soil Sci. Soc. Am. J., 44, 892-898, 1980.

Vázquez, N., Pardo, A., Suso, M. L., \& Quemada M. (2006). Drainage and nitrate leaching under processing tomato growth with drip irrigation and plastic mulching. Agriculture Ecosystems and Environment, 112 (4), 313-323.

Wang, P., Song, X. F., Han, D. M., Zhang, Y. H., \& Zhang B. (2012). Determination of evaporation, transpiration and deep percolation of summer corn and winter wheat after irrigation. Agricultural Water Management, 105, 32-37.

Wang, L., Caylor, K.K., Villegas, J.C., Barron-Gafford, G.A., Breshears, D.D., Huxman, T.E., 2010. Partitioning evapotranspiration across gradients of woody plant cover: assessment of a stable isotope technique. Geophys. Res. Lett. 37, L09401. 
Wallor, E., Rosskopf, N., Zeitz, J. 2018. Hydraulic properties of drained and cultivated fen soils part I - Horizon-based evaluation of van Genuchten parameters considering the state of moorsh-forming process. Geoderma, 313, 6981.

Wenninger, J., Beza, D.T., Uhlenbrook, S., 2010. Experimental investigations of water fluxes within the soil-vegetation-atmosphere system: stable isotope mass balance approach to partition evaporation and transpiration. Phys. Chem. Earth Parts A/B/C 35, 565-570.

Willis, T.M.; Scott Black, A. \& Meyer, S.W. 1997. Estimates of deep percolation beneath cotton in the Macquarie Valley. Irrig. Sci., 17:141-150, 1997.

Xue Q., Zhu Z., Musick, J.T., Stewart, B. A., Dusek, D. A. 2003. Root growth and water uptake in winter wheat under deficit irrigation. Plant and Soil 257: 151161.

Xu, B., Shao, D., Tan, X., Yang, X., Gu, W., Li, H. 2017. Evaluation of soil water percolation under different irrigation practices, antecedent moisture and groundwater depths in paddy fields.A gricultural Water Management, 192 (2017) 149-158.

Zhang, Y., Liu, C., Shen, Y., Kondoh, A., Tang, C., Tanaka, T., Shimada, J., 2002. Measurement of evapotranspiration in a winter wheat field. Hydrol. Processes 16 (14), 2805-2817.

Zhang, Y., Shen, Y., Sun, H., Gates, J.B., 2011. Evapotranspiration and its partitioning in an irrigated winter wheat field: A combined isotopic and micrometeorologic approach. J. Hydrol. 408 (3), 203-211.

Zheng, C., Lu, Y., Guo, X., Li, H., Liu, X. 2017. Application of HYDRUS-1D model for research on irrigation infiltration characteristics in arid oasis of northwest China. Environ Earth Sci 76, 785 (2017). https://doi.org/10.1007/s12665-0177151-2. 